\title{
Gambaran Sarapan dan Status Gizi Pada Mahasiswa Fakultas Kedokteran Universitas Riau Angkatan 2017
}

\author{
Isnani Kurniyanti ${ }^{1}$, Erwin Christianto ${ }^{2}$, Ismawati ${ }^{3 *}$
}

\begin{abstract}
Breakfast is an activity of eating and drinking between waking up to 9 am to fulfill some of the daily nutritional needs (15-30\% nutritional needs). The benefits of breakfast are maintaining an ideal body weight because breakfast can reduce the amount of food you eat throughout the day. The purpose of this study was to find out the description of breakfast and Body Mass Index (BMI) in students of the Faculty of Medicine, University of Riau in 2017. This research was descriptive study with 121 samples. The results showed $16.3 \%$ obese I and $8.1 \%$ obese II. Respondents with good breakfast calories tend to have good nutritional status of $50.0 \%$.
\end{abstract}

Keywords: Breakfast, Student, Body Mass Index.

Undang-undang Nomor 36 tahun 2009 tentang kesehatan pasal 141 ayat 1 mengatakan bahwa upaya perbaikan gizi masyarakat ditujukan untuk peningkatan mutu gizi perseorangan dan masyarakat. ${ }^{1}$ Perilaku penting yang dapat membantu perbaikan gizi seseorang adalah pola makan karena makanan serta minuman yang dikonsumsi memengaruhi kesehatan. Tubuh yang sehat akan terhindar dari berbagai penyakit kronis atau penyakit tidak menular terkait gizi, oleh karena itu keteraturan pola makan dengan gizi seimbang menjadi penting. ${ }^{2}$

Prevalensi status gizi lebih di Indonesia mengalami peningkatan yang signifikan yaitu pada laki-laki 13,9\% pada tahun 2007 menjadi $19,7 \%$ pada tahun 2013 dan pada perempuan, tahun 2007 23,8\% menjadi $32,9 \%$ pada tahun 2013 . Berbeda dengan prevalensi gizi kurang yang mengalami penurunan berdasarkan Indeks Massa Tubuh (IMT) pada tahun $200714,8 \%$ menjadi $6,3 \%$ tahun $2013 .{ }^{3,4}$ Ada beberapa faktor yang mempengaruhi status gizi antara lain umur, aktivitas fisik, keadaan fisiologis tubuh, ${ }^{5}$ pola makan, faktor psikologis, pendidikan dan pengetahuan serta jenis kelamin. ${ }^{6}$

\footnotetext{
* Korespondensi penulis : email: ismawati75@yahoo.com

1 Mahasiswa Fakultas Kedokteran Universitas Riau

KJFD Ilmu Gizi Fakultas Kedokteran Universitas Riau

KJFD Biokimia Fakultas Kedokteran Universitas Riau
}

Sarapan adalah kegiatan makan dan minum yang dilakukan antara bangun tidur pagi sampai jam 9 pagi untuk memenuhi sebagian kebutuhan gizi harian (15-30\% kebutuhan gizi) dalam rangka mewujudkan hidup sehat, aktif, cerdas dan produktif., ${ }^{2,7}$ Masih banyak masyarakat Indonesia yang belum membiasakan untuk sarapan. Tidak sarapan dapat mengakibatkan dampak buruk terhadap prestasi belajar di sekolah, menurunkan aktivitas fisik, menyebabkan kegemukan dan meningkatkan risiko jajan yang tidak sehat. Membiasakan sarapan pagi berarti membiasakan diri untuk disiplin bangun pagi dan beraktivitas pagi serta mencegah makan berlebihan saat makan siang dan kudapan. $^{2}$

Pada sarapan perlu diperhatikan kandungan nutrisi dan energi yang dihasilkannya. Penelitian yang dilakukan pada anak sekolah dasar di Pedurungan Kota Semarang menyatakan bahwa anak yang tidak sarapan akan jajan di sekolah sebanyak 43,76\%, sedangkan anak yang biasa sarapan dan tidak jajan sebanyak $28,12 \%$. Hasil dari penelitian ini menyatakan bahwa terdapat hubungan antara kebiasaan sarapan dengan kebiasaan jajan anak disekolah. Anak yang tidak biasa sarapan dirumah akan berisiko 1,5 kali lipat untuk jajan, sehingga dapat meningkatkan risiko 7 kali lipat lebih besar untuk terjadi status gizi berlebih. ${ }^{8}$ Hasil yang sama juga 
didapatkan oleh Arraniri yang menyatakan bahwa terdapat hubungan antara sarapan dengan presentase lemak tubuh. ${ }^{9}$ Penelitian yang dilakukan pada siswa SMP Bosowa Bina Insani Bogor menyatakan hasil yang berbeda dengan penelitian diatas. Penelitian ini dilakukan pada 53,3\% perempuan dan $46,7 \%$ laki-laki. Penelitian ini menyatakan bahwa tidak terdapat perbedaan status gizi antara siswa yang sarapan dengan yang tidak sarapan. ${ }^{10}$

Berdasarkan latar belakang tersebut, penelitian ini bertujuan untuk mengetahui gambaran kebiasaan sarapan dan status gizi pada mahasiswa Fakultas Kedokteran Universitas Riau angkatan 2017.

\section{METODE}

Penelitian ini menggunakan metode deskriptif dengan total sampling yang mencakup semua populasi yang ada. Penelitian ini dilaksanakan di
Fakultas Kedokteran Universitas Riau pada Bulan Oktober 2017 sampai Juli 2018.

\section{HASIL}

\section{Gambaran umum subjek penelitian}

Populasi dari penelitian ini adalah mahasiswa Fakultas Kedokteran Universitas Riau angkatan 2017. Laki-laki sebanyak 36 responden dan perempuan sebanyak 85 responden. Jumlah keseluruhan responden 121 orang.

\section{Gambaran aktivitas fisik, pengetahuan gizi, status gizi, frekuensi sarapan dan kecukupan kalori sarapan}

Distribusi aktivitas fisik responden, pengetahuan gizi, status gizi, frekuensi sarapan dan kecukupan kalori sarapan dapat dilihat pada tabel 1.

Tabel 1. Aktivitas fisik, pengetahuan gizi, status gizi, frekuensi sarapan dan kecukupan kalori sarapan

\begin{tabular}{|c|c|c|}
\hline Variabel & Jumlah & Persentase \\
\hline $\begin{array}{c}\text { Aktivitas Fisik } \\
\text { - } \quad \text { Ringan } \\
\text { - } \quad \text { Sedang } \\
\text { - } \quad \text { Berat }\end{array}$ & $\begin{array}{r}121 \\
0 \\
0\end{array}$ & $\begin{array}{c}100 \% \\
0 \% \\
0 \%\end{array}$ \\
\hline $\begin{array}{cl}\text { Pengetahuan Gizi } \\
\text { - } & \text { Baik } \\
\text { - } & \text { Cukup } \\
\text { - } & \text { Kurang }\end{array}$ & $\begin{array}{c}8 \\
98 \\
15\end{array}$ & $\begin{array}{c}6,6 \\
81,0 \\
12,4\end{array}$ \\
\hline $\begin{array}{cl}\text { Status Gizi } \\
\text { - Underweight } \\
\text { - } \text { Normal } \\
\text { - Overweight } \\
\text { - Obese I } \\
\text { - Obese II }\end{array}$ & $\begin{array}{c}15 \\
60 \\
18 \\
17 \\
11\end{array}$ & $\begin{array}{c}12,4 \\
49,6 \\
14,9 \\
14 \\
9,1\end{array}$ \\
\hline $\begin{array}{cl}\text { Frekuensi sarapan permi } \\
\text { - Setiap hari } \\
\text { - Kadang-kadang } \\
\text { - } & \text { Tidak pernah }\end{array}$ & $\begin{array}{c}5 \\
31 \\
86\end{array}$ & $\begin{array}{c}4,1 \\
25,6 \\
70,2\end{array}$ \\
\hline $\begin{array}{cl}\text { Kecukupam kalori } \\
\text { • } \\
\text { - } \\
\text { - } & \text { Baik } \\
\text { Lebih }\end{array}$ & $\begin{array}{c}1 \\
28 \\
7\end{array}$ & $\begin{array}{c}2,8 \\
77,8 \\
19,4\end{array}$ \\
\hline
\end{tabular}


Pada tabel 1. terlihat untuk aktivitas fisik semua responden memiliki aktivitas fisik ringan, sebagian besar pengetahuan gizi responden cukup yaitu sebanyak 98 responden (81\%) dan sebanyak 60 responden $(49,6 \%)$ memiliki status gizi normal.

Hasil penelitian menunjukkan bahwa sebagian besar responden tidak pernah sarapan. Berdasarkan hasil penelitian responden yang setiap hari sarapan dan kadang-kadang sebanyak 36 responden. Kecukupan kalori sarapan 28 responden (77,8\%) termasuk kategori baik.

Distribusi sarapan dan status gizi pada penelitian ini dibagi menjadi 2 bagian yaitu: distribusi frekuensi sarapan dan status gizi responden dapat dilihat pada tabel 2. serta kecukupan kalori sarapan dan status gizi responden dapat dilihat pada tabel 3 .

Tabel 2. Frekuensi sarapan dan status gizi responden

\begin{tabular}{|c|c|c|c|c|c|c|c|c|c|c|c|c|}
\hline \multirow{3}{*}{$\begin{array}{l}\text { Frekuensi } \\
\text { Sarapan }\end{array}$} & \multicolumn{10}{|c|}{ Status Gizi } & \multicolumn{2}{|c|}{ Jumlah } \\
\hline & \multicolumn{2}{|c|}{ Underweight } & \multicolumn{2}{|c|}{ Normal } & \multicolumn{2}{|c|}{ overweight } & \multicolumn{2}{|c|}{ Obese I } & \multicolumn{2}{|c|}{ Obese II } & \multirow[b]{2}{*}{$\mathrm{n}$} & \multirow[b]{2}{*}{$\%$} \\
\hline & $\mathrm{N}$ & $\%$ & $\mathrm{~N}$ & $\%$ & $\mathrm{n}$ & $\%$ & $\mathrm{~N}$ & $\%$ & $\mathrm{n}$ & $\%$ & & \\
\hline Setiap hari & 0 & 0 & 2 & 40 & 3 & 60 & 0 & 0 & 0 & 0 & 5 & 100 \\
\hline $\begin{array}{l}\text { Kadang- } \\
\text { kadang }\end{array}$ & 5 & 16,7 & 14 & 46,7 & 4 & 13,3 & 3 & 10,0 & 4 & 13,3 & 30 & 100 \\
\hline Tidak pernah & 10 & 11,6 & 44 & 51,2 & 11 & 12,8 & 14 & 16,3 & 7 & 8,1 & 86 & 100 \\
\hline Jumlah & 15 & 12,4 & 60 & 49,7 & 18 & 14,9 & 17 & 14,1 & 11 & 9,1 & 121 & 100 \\
\hline
\end{tabular}

Berdasarkan hasil penelitian didapatkan hasil responden yang sarapan setiap hari memiliki status gizi normal dan overweight masing-masing sebesar $40 \%$ dan $60 \%$. Responden yang sarapan kadangkadang sebagian besar memiliki status gizi normal $46,7 \%$ dan responden yang tidak terbiasa sarapan memiliki status gizi normal sebanyak 51,2\%.
Sedangkan perbedaan yang cukup jelas terlihat pada status gizi obese I dan obese II, responden yang sarapan setiap hari tidak ada $(0 \%)$ yang obese I dan obese II, sedangkan responden yang sarapan kadang-kadang memiliki status gizi obese I 10\% dan obese II 13,3\%. Responden yang tidak pernah sarapan memiliki status gizi obese I $16,3 \%$ dan obese II $8,1 \%$.

Tabel 3. Kecukupan kalori sarapan dan status gizi

\begin{tabular}{|c|c|c|c|c|c|c|c|c|c|c|c|c|}
\hline \multirow{3}{*}{$\begin{array}{l}\text { Kecukupan } \\
\text { kalori } \\
\text { Sarapan }\end{array}$} & \multicolumn{10}{|c|}{ Status Gizi } & \multicolumn{2}{|c|}{ Jumlah } \\
\hline & \multicolumn{2}{|c|}{ Underweight } & \multicolumn{2}{|c|}{ Normal } & \multicolumn{2}{|c|}{ Overweight } & \multicolumn{2}{|c|}{ Obese I } & \multicolumn{2}{|c|}{ Obese II } & \multirow[b]{2}{*}{$\mathrm{n}$} & \multirow[b]{2}{*}{$\%$} \\
\hline & $\mathrm{n}$ & $\%$ & $\mathrm{n}$ & $\%$ & $\mathrm{n}$ & $\%$ & $\mathrm{n}$ & $\%$ & $\mathrm{n}$ & $\%$ & & \\
\hline Kurang & 0 & 0 & 0 & 0 & 0 & 0 & 1 & 100 & 0 & 0 & 1 & 100 \\
\hline Baik & 3 & 10,7 & 14 & 50,0 & 7 & 25,0 & 1 & 3,6 & 3 & 10,7 & 28 & 100 \\
\hline Lebih & 2 & 28,6 & 3 & 42,9 & 0 & 0 & 1 & 14,3 & 1 & 14,3 & 7 & 100 \\
\hline Jumlah & 5 & 13,9 & 17 & 47,2 & 7 & 19,5 & 3 & 8,3 & 4 & 11,1 & 36 & 100 \\
\hline
\end{tabular}

Berdasarkan hasil penelitian responden yang memiliki kebiasaan sarapan dengan kecukupan kalori sarapan yang kurang sebanyak 1 orang memiliki status gizi obese I. Responden yang sarapan dengan kecukupan kalori sarapan yang baik memiliki status gizi normal sebanyak 14 orang (50\%). Responden yang sarapan dengan kecukupan kalori sarapan yang lebih memiliki status gizi normal sebanyak 3 orang (42,9\%). Responden yang sarapan memiliki status gizi normal sebesar $47,2 \%$.

\section{PEMBAHASAN}

Pada penelitian ini didapatkan responden dengan jenis kelamin laki-laki sebanyak 36 responden $(29,8 \%)$ dan perempuan sebanyak 85 responden $(70,2 \%)$. Berdasarkan penelitian ini didapatkan hasil bahwa seluruh responden melakukan aktivitas fisik ringan. Aktivitas fisik ringan meliputi 8 jam tidur, 7 jam belajar atau duduk, 2 jam pekerjaan sedang di rumah tangga, 1,5 jam 
berolahraga, 6,5 jam pekerjaan ringan dan sangat ringan. ${ }^{11}$ Hasil penelitian menunjukkan bahwa responden yang memiliki pengetahuan gizi baik hanya 8 orang $(6,6 \%)$. Responden yang memiliki pengetahuan gizi cukup mendominasi yaitu sebanyak 98 orang $(81,0 \%)$. Kurangnya pengetahuan gizi reponden dapat menyebabkan responden tidak mengkonsumsi sumber zat gizi yang seimbang pada saat makan. Rendahnya pengetahuan gizi juga memengaruhi banyaknya responden yang tidak sarapan. Hasil pada penelitian ini meningkat pada pengetahuan gizi cukup dibandingkan penelitian yang dilakukan dwijayanti yaitu pengetahuan gizi cukup sebesar $53,66 \% .^{12}$ Hasil penelitian menunjukkan bahwa status gizi pada responden penelitian ini baik mendominasi sebesar 60 orang $(49,6 \%)$. Hal ini berbeda dengan hasil Riskerdas yang menyatakan bahwa persentase status gizi baik di Indonesia sebesar $62,68 \%$. Prevalensi status gizi baik pada daerah Riau sebesar 65,39\%. ${ }^{4}$ Hasil pada penelitian ini sedikit rendah pada status gizi baik daripada Riskerdas 2013. Berdasarkan penelitian ini dapat dilihat bahwa dari 121 responden, dominan responden tidak pernah sarapan atau sarapan tetapi tidak termasuk kategori sarapan karena tidak terdiri dari sumber gizi seimbang atau tidak sesuai dengan waktu yang ditetapkan untuk sarapan yaitu 70,2\%. Hal ini berbeda dengan penelitian yang dilakukan oleh Dwijayanti bahwa responden yang tidak sarapan sebanyak $23,17 \% .{ }^{12}$ Tingginya persentase yang tidak sarapan pada penelitian ini dikarenakan banyak mahasiswa yang makan pada pagi hari tetapi tidak memenuhi persyaratan sarapan yaitu makanan harus terdiri dari sumber gizi seimbang. Makanan yang dikonsumsi harus mengandung makanan pokok, lauk pauk dan sayur atau buah. ${ }^{2}$

Kecukupan kalori sarapan harus memenuhi 15$30 \%$ kebutuhan energi harian, pada penelitian ini kebutuhan energi harian dihitung secara individual. Komposisi zat gizi setiap jenis memiliki keunggulannya dan kelemahan, supaya seimbang kita harus mengkonsumsi makanan yang terdiri dari sumber zat gizi seimbang. ${ }^{2}$ Pada penelitian ini sebagian besar responden makan pada pagi hari tetapi tidak terdiri dari sumber gizi seimbang sehingga tidak termasuk kategori sarapan.Responden pada penelitian ini terdiri dari 121 orang dan responden yang sarapan sebanyak 36 orang. Responden dengan kecukupan kalori sarapan yang baik sebanyak 28 orang $(77,8 \%)$ dari 36 orang (29,8\%) yang sarapan dalam satu minggu. Responden yang sarapan dengan sumber zat gizi yang lengkap dan kecukupan kalori baik di dapatkan mendominasi pada responden yang sarapan pada penelitian ini. Berdasarkan Riskerdas 2015 prevalensi pada daerah Riau kebutuhan energi sangat kurang sebesar $(<70 \%$ AKE) $50 \%$ dan kebutuhan energi kurang sebesar 35\% (70\% sampai $<100 \%$ AKE). ${ }^{13}$

Hasil penelitian ini menunjukkan bahwa responden yang sarapan setiap hari tidak ada yang memiliki status gizi obese I dan obese II. Responden yang sarapan kadang-kadang memiliki status gizi obese I sebanyak 10\% dan obese II sebanyak $13,3 \%$. Responden yang tidak pernah sarapan dan memiliki status gizi obese I sebanyak $16,3 \%$ dan obese II sebanyak $8,1 \%$. Pada penelitian yang dilakukan oleh Dwijayanti mendapatkan hasil bahwa responden yang sarapan 3 sampai 5 kali dalam seminggu memiliki status gizi lebih sebesar 55,56\% dan responden yang tidak pernah sarapan memiliki status gizi lebih sebesar $11,11 \% .{ }^{12}$ Adanya perbedaan hasil pada penelitian tersebut dikarenakan adanya perbedaan pengelompokan status gizi lebih. Pada penelitian ini status gizi lebih dikategorikan lagi menjadi overweight, obese I dan obese II sedangkan pada penelitian Dwijayanti digabungkan dan tidak dikelompokkan.

Hasil penelitian menunjukkan bahwa responden yang mengkonsumsi kalori sarapan baik memiliki status gizi normal sebesar 50\%. Responden yang menkonsumsi kalori sarapan lebih memiliki status gizi normal sebesar $42,9 \%$. Responden yang mengkonsumsi kalori sarapan kurang memiliki status gizi obese I. Hasil yang didapatkan pada penelitian ini sejalan dengan penelitian yang dilakukan oleh Pertiwi yang mendapatkan hasil bahwa tidak ada hubungan antara kecukupan energi sarapan terhadap status gizi. ${ }^{14}$ Penelitian yang dilakukan oleh Schusdziarra mendapatkan hasil yang sebaliknya bahwa asupan kalori sarapan yang baik memiliki korelasi positif dan signifikan dengan asupan energi total harian dan berat badan. ${ }^{15}$

\section{SIMPULAN}

Jumlah responden pada penelitian ini 121 orang, dominan subjek dengan jenis kelamin perempuan 85 
orang $(70,2 \%)$. Semua responden memiliki aktivitas fisik ringan. Sebagian besar responden memiliki pengetahuan cukup. Status gizi normal terdapat pada $49,6 \%$ responden dan sebagian besar responden tidak sarapan. Responden yang sarapan sebagian besar memiliki kecukupan kalori yang baik. Perbandingan antara frekuensi sarapan dan status gizi, sebagian besar responden yang tidak sarapan dan memiliki status obese I. Kecukupan kalori sarapan dan status gizi, banyak responden yang sarapan dengan kecukupan kalori yang baik dan memiliki status gizi yang baik.

\section{DAFTAR PUSTAKA}

1. Kementrian Kesehatan Republik Indonesia. Undang-undang Republik Indonesia No. 36 tahun 2009 tentang kesehatan. 2009;111.

2. Kementrian Kesehatan Republik Indonesia. Pedoman gizi seimbang. Jakarta: Kementrian kesehatan RI.2014. 1-94.

3. Badan Penelitian dan Pengembangan kesehatan. Riset kesehatan dasar. Jakarta: Departemen kesehatan RI; 2008. 1-290.

4. Kementrian Kesehatan. Profil kesehatan Indonesia Tahun 2013 [Internet]. Jakarta: Kementerian Kesehatan RI. 2014. 507 p. Available from: http://scholar.google.com/ scholar?hl=en\&btnG= Search\&q=i ntitle:Profil + Data + Kesehatan+Indonesia + Tahun $+2011 \# 0$

5. Purwitasari D, Maryanti D. Gizi dalam kesehatan reproduksi. 1st ed. Setiawan A, editor. Yogyakarta: Nuha Medika; 2009.

6. Fakultas Kesehatan Masyarakat Universitas Indonesia, Departemen Gizi Dan Kesehatan Masyarakat. Gizi dan kesehatan masyarakat. 6th ed. Jakarta: PT Rajagrafindo Persada; 2011.
7. International Food Information Council Foundation. Breakfast and health. IFIC Rev. 2008;(9):1-17.

8. Mariza YY. Hubungan antara kebiasaan sarapan dan jajan dengan status gizi pada anak sekolah dasar di Kecamatan Pedurungan Kota Semarang. Journal of Nutrition College. 2013;1(1):207-13.

9. Arraniri M, Desmawati, Aprilia D. Hubungan kebiasaan sarapan dan asupan kalori dengan persentase lemak tubuh pada mahasiswa Prodi Profesi Dokter Fakultas Kedokteran Universitas Andalas angkatan 2013-2015. Jurnal Kesehatan Andalas. 2016;6(2):265-70.

10.Niswah I, Damanik MRM, Ekawidyani KR. Kebiasaan sarapan, status gizi, dan kualitas hidup remaja SMP Bosowa Bina Insani Bogor. J Gizi dan Pangan. 2014;9(10):97-102.

11. Nugraini S. Ilmu Gizi 2. Jakarta: Kementrian Pendidikan dan kebudayaan; 2013. 66-67.

12.Dwijayanti RI, Rohmawati N, Ningtyias FW. Gambaran absenteisme makan pagi dan status gizi pada mahasiswa di Fakultas Keguruan Dan Ilmu Pendidikan Universitas Jember [skripsi]. Jember: Universitas Jember; 2016.

13. Kemenkes RI. Profil kesehatan Indonesia. Vol. 70, Kesehatan. Kementrian Kesehatan Republik Indonesia; 2016. 1-222 p.

14.Pertiwi I, Sandjaja, Wiyono S. Hubungan sarapan , kecukupan energi dan protein Provinsi Lampung ( analisa data sekunder riskesdas 2010 ). Univ ersitas Esa Unggul. 2014;6:1-8.

15.Schusdziarra V, Hausmann M, Wittke C, Mittermeier J, Kellner M, Naumann A, et al. Impact of breakfast on daily energy intake - An analysis of absolute versus relative breakfast calories. Nutr J [Internet]. 2011;10(1):5. Available from: http://www.nutritionj.com/content/10/1/5 